\title{
Literature Review of Mergers and Acquisitions with the Aim to Obtain Technology and Knowledge
}

\author{
Elena Ochirova \\ PhD Student \\ $\underline{\text { ORCID }}$ \\ E-mail: eochirova@hse.ru
}

School of Finance, National Research University Higher School of Economics, Moscow, Russia

Journal of Corporate Finance Research, Vol. 13, No. 4, pp. 87-94 (2019)

DOI: https://doi.org/10.17323/j.jcfr.2073-0438.13.4.2019.87-94

Received 10 September 2019 | Peer-reviewed 5 October 2019 | Accepted 3 December 2019 


\section{Literature Review of Mergers and Acquisitions with the Aim to Obtain Technology and Knowledge}

\section{Abstract}

Technological transformation of the economy is pushing companies to create or improve their technological capabilities. One of the ways to acquire technology and knowledge that allows companies to remain competitive is mergers and acquisitions (M\&A). The efficiency and motives of M\&A transactions with motivation of obtaining new technology and knowledge are the subject of a large number of studies. The contradictory results of studies of technological M\&A transactions can be explained by the gaps of the empirical analysis or the weakness of the theoretical knowledge. The purpose of this study is to review the theoretical works on the effectiveness of M\&A transactions in order to acquire technology and knowledge, and to identify the main results in this area. In particular, the motives of technological M\&A deals were identified; the technological overlap of the parties of the M\&A transactions and the relationship between the intensity of R\&D expenses, innovative activity and company efficiency were described. In order to identify the relevant key determinants of the effectiveness of technological M\&A transactions the motives of traditional M\&A transactions were also examined. As a result of the analysis, it was revealed that the technological similarity between the acquiring and acquired companies have positive effect on the reaction of investors and on the effectiveness of the transaction, however, it negatively affects the overall effectiveness of the buyer company. The intensity of R\&D expenses and innovative activity demonstrate inconsistent results on companies' performance. Factors that have direct or indirect impact on the integration between companies - have contradictory results on both parties of a deal. Based on the existed literature the effectiveness of M\&A transactions with the aim of acquiring technology and knowledge is associated with uncertainty for investors caused by the risks of such transactions in different sectors of the economy, the motives of managers and the characteristics of the parties of the transactions.

Keywords: mergers and acquisitions, innovation, efficiency of mergers and acquisitions JEL classification: G34, O32 


\section{Introduction}

Under modern rapidly changing conditions technological development increases influence on various economy sectors [1-3] and plays a significant part in improving competitiveness, productivity and, in general, in successful performance of companies. Many companies have to develop new business models, adapt to technological changes, implement actively technologies into production and develop their potential of technological capabilities [4]. However, some companies face difficulties when they create their own innovative technologies because they have no necessary knowledge and skills [5-6]. One of the ways of acquiring technological knowledge and developments which are beyond their powers is mergers and acquisitions (M\&A) [7-9]. M\&A deals may be a part of the strategy of company development and efficiency improvement [10-12]. Apart from that, it is presumed in scientific literature that increasing complexity of technologies is one of the main determinants of mergers and acquisitions waves [13-14]. According to R. Frey and K. Hussinger [15] due to mergers and acquisitions companies may reorganize effectively their own technologies and to improve significantly their technology expertise. So, the question arises: what the degree of effectiveness of mergers and acquisitions in order to acquire technologies and knowledge is for financial indicators of a company and what their main determinants are.

In general, M\&A may bring about various results for the parties of a deal [16]. Some researches in the field of mergers and acquisitions showed destruction of value of the acquiring company while others found a positive excessive yield or a zero yield [17-18]. Researchers assert that the mixed influence on company shares' profitability is caused by the fact that investors, depending on specifics of transactions, evaluate expectations in regard to the transaction synergistic effect differently [19]. For example, P. Asquith [20], found out that acquiring companies from the list of Fortune 1000 within 1963-1979 got a significant excessive profitability $[+2,8 \%]$ from transactions within the events window $[-20,0]$. E. Berkovitch and M. P. Narayanan [21] assumed that the reason for the positive yield of M\&A deals was the synergy motives when managers of the target and acquiring companies took part in the deal only if it maximized the welfare of shareholders of both parties. In scientific papers on mergers and acquisitions operating and financial synergy is distinguished, the first one is intended to improve efficiency of the acquiring company due to the capacity and scope effect while the second synergy is aimed at decrease of investment costs due to reduction of investment risk [22-23]. If the acquired company has been overestimated and its intangible assets lose in value in course of time it may cause negative results for the acquiring company. The other reason for difference in results for M\&A deals may be the time interval of evaluating the deal effects. As a rule, investors of the acquiring company get an excess profitability in the short term or in a smaller event window, for example, $[-1,0]$ or $[-1,1][11]$. T. Loughran and
A. Vijh [24] found out that although in general investors of acquired companies got a high excess profitability in the immediate future, at a longer period such profitability became insignificant. R.J. Rosen [25] discovered that in case of a low activity in the M\&A market the acquiring companies had a high profitability in the short term, while in the long term the profitability of the buying company declined. Efficiency of the companies' integration may also be attributed to corporate and cultural differences [26].

\section{Motivation of M\&A Deals Aimed at Purchase of Technologies and Knowledge}

Motivation of M\&A deals in order to purchase technologies and knowledge may be highly specific for various economy sectors. S. Ma and Z. Liu [27] distinguished several motives of M\&A deals for the purpose of purchasing technologies and knowledge: expansion to a new market segment or diversification; sophistication of a company's technology; possibility of growth of the acquiring company when a large buyer, instead of investments into its own research and development (R\&D), preferred to purchase advancements in technology from a relatively small acquired company. According to Y. Konchitchki and D.E. O'Leary [28] the key motive for implementation of advanced technologies by the companies is attaining a technological competitive advantage. The authors found out that companies got a significant excess profitability when they announced implementation of various information technologies or related information systems in the company operations which indicated a positive investors' response. Generally, the literature dedicated to M\&A deals intended to purchase technologies and knowledge is indicative of the positive excess profitability for the acquired, as well as for the acquiring company [29-31]. N. Kohers and T. Kohers [30] studied short-term results of M\&A deals of American high-tech companies and found out a significant positive effect irrespective of the manner of payment: by money transfers or shares. In the research dedicated to study of the effects of purchase of technologies the authors G. Benou and J. Madura [29] also discovered a positive market response. A. Deshmukh [32] studied M\&A deals in the field of information technologies, software and Internet where the average excess profitability on the day of announcement amounted to + $1.23 \%$. However, science-based and innovative sectors which also comprise IT depend much more on certain skills and experience and, consequently, they may face management problems as a result of M\&A [33]. Thus, one may come to the conclusion that the stock market response to announcements about mergers and acquisitions of technology companies is related to the investors' uncertainty as regards the fair value of shares whether they are representatives of the acquiring company, or the acquired company. 
In addition to the above, the motivation to implementation of technologies may also be the companies' desire to cut down expenses, increase sales and attain operating efficiency. M\&A deals are more successful if the buyer company and the target company have technological similarities as long as it facilitates overcoming a significant informational asymmetry [34-35]. If the implemented technology is in line with the company's business and implies improvement of its operating efficiency the positive market response is anticipated. Successful results of a M\&A deal depend on the degree to which internal research and development of the acquiring company correspond to the purchased technologies and knowledge [3]. Existence of corresponding internal research and development in possession of the acquiring company is one of the key preconditions of effectiveness of an M\&A deal because it helps to gain the knowledge of the acquired company in a better way.

Technological similarity of the parties of an M\&A deal results in operating reorganization of the merged company. According to V. Maksimovic [36] within the first 3 years after acquisition duplicates of developments are replaced, research laboratories are united. This results in shutdown and sale of $18 \%$ and $27 \%$ of factories of the acquired company respectively. After M\&A deals of technologically similar companies a greater number of employee termination is observed [37]. M. Colombo and L. Rabbiosi [38] found out that termination of staff did not bring about increase in productivity of $\mathrm{R} \& \mathrm{D}$ while replacement of senior executives of the merged company could improve this figure. Thus, M\&A in order to purchase technological capabilities of the target company aiming at operating synergy depend on the degree of technological similarity of companies. Existence of similarities in the technological development of the companies involved in M\&A has a positive influence on investors' response as well as on the deal efficiency, but the excessive number of duplicate research and development affects the total efficiency of the buyer company.

\section{Determinants of M\&A Deals Efficiency Aimed at Purchase of Technology and Knowledge}

M\&A deals in order to purchase technologies and knowledge become an intrinsic part of research papers on M\&A in general [39-40]. A series of studies is focused on the interrelation between the rate of $\mathrm{R} \& \mathrm{D}$ expenditures and companies' efficiency [41]. D.R. King [41] found out that target companies with a significant amount of R\&D investments in comparison to the companies with low expenditures for research and development create a higher excess profitability for the buyer companies. However, in accordance with the research by G. Ahuja and R. Katila [42] if the target company has a larger number of its own developments in comparison to the acquiring company the efficiency of such deal is lower because in this case the buyer company experiences difficulties in gaining new knowledge and applying it for commercial purposes. Influence of M\&A deals on the innovative activity intensiveness of a company is controversial [43]. According to V. Baesu [44] there is a positive correlation between the number of employees involved in R\&D and innovations. Besides, the authors found out that high R\&D costs result in decrease of the company innovative activity which in its turn may be indicative of poor expenditure effectiveness. However, such results may be evidence of the unique character of the developed product. Companies focus on carrying out of individual ideas and their innovative activity is hinged on one specific field. A series of studies indicates that, as a rule, buyers are the companies with a significant number of patents and rather low R\&D expenditures [45]. According to F. Szücs [46] the acquiring company makes its choice on a case-by-case basis mainly taking over the companies with high $\mathrm{R} \& \mathrm{D}$ expenses. Besides, the author revealed the regularity of R\&D investment quote and found out that within 5 years after the purchase the target company as well as the buyer company had decreased R\&D costs and intensiveness, then the indicators came back to their normal value. M.A. Hitt [4] discovered that M\&A deals adversely affected $\mathrm{R} \& \mathrm{D}$ investments and efficiency of buyer companies.

It is of importance that effects of various developed or purchased technologies vary considerably [47]. According to F.M. Scherer and D. Harhoff [48] approximately $10 \%$ of created and patented innovations may account for $93 \%$ of all subsequent positive financial results. Often in the studies the values of the rate of R\&D expenditures and its variations serve as a guidemark for defining the existing companies' fund of knowledge while quantitative and qualitative evaluation of patents may be construed as a result of operations, i.e. the innovative activity. The relation between these two indicators is sometimes ambiguous and this is reflected on empiric results of researches.

The literature also pays attention to defining determinant characteristics involved in M\&A of the companies which influence the efficiency of mergers and acquisitions in order to purchase technologies and knowledge [49]. The research by G.Benou and J. Madura [29] showed that the acquiring company's previous experience of M\&A deals and the transaction value had positive effect on excess profitability while R\&D expenditures adversely affected the profitability. Similarly, P. Porrini [50] studied transactions of high-tech companies and found out that previous M\&A experience brought about positive results for the buyer company and negative results - for the target company. The buyer company's experience in M\&A deals may be a positive sign for investors, i.e. it is indicative of a possible, relatively high speed of integration of the acquired company. The opposite results for the target company probably show significance for investors of the risk of management's opportunist behavior. Against the background of intensive competition, the previous experience in M\&A for the acquiring company may play a crucial part in M\&A deals in order to purchase technologies and 
knowledge because it facilitates quick commercialization of the purchased technologies and accelerated integration in organization.

There is a large number of researches of efficiency of cross-border and local M\&A transactions [51-52]. According to A. Boateng [53] cross-border M\&A are often the deals in order to purchase technologies and knowledge protected by patents. Some technologies are developed and patented only for the domestic market. Under such conditions other efficient ways of gaining knowledge, apart from purchase of a company together with technologies, do not exist. Studies of efficiency of international and local mergers and acquisitions in tech-intensive sectors show that cross-border deals are more efficient than local ones [54]. It was proved that in case the acquiring and the target company belonged to tech-intensive sectors the excess profitability in international transactions was much higher than in local ones [55-56]. The research by J. Hagedoorn and G. Duysters [57] on average cross-border M\&A deals shows a higher technological efficiency. Francoeur [58] makes a point that R\&D expenses of the acquiring company are an important factor in achieving an excess profitability in international M\&A deals. Besides, the technological development level of the country where the buyer and target companies operate influences the efficiency, and this is related to availability of opportunities for a successful commercialization of purchased technologies [59].

Proceeding from the type of integration of the merging companies horizontal, vertical and conglomerate M\&A deals are usually distinguished [27]. Horizontal mergers and acquisitions take place between competitors of the same industry and it implies that technologies of such companies should be similar. In case of such integration the company mainly experiences the operational synergy effect. In its turn, the vertical integration occurs when a company mergers with a supplier or buyer of its products. Such mergers and acquisitions may generate additional value provided the company has assets of narrow specialization. In this case the vertical integration provides for a better coordination when using complementary, highly specialized resources at all stages of the production cycle [60]. Conglomerate mergers and acquisitions are aimed at diversification of operations and products of the buyer company. According to J. Hagedoorn and G. Duysters [57] only vertical and horizontal mergers may be called technologically congruous while conglomerate mergers take place among the companies which have no technological relation. Apart from that, the authors found out that horizontal and vertical M\&A deals made by the companies which invest actively in research and development upgrade their common technological capabilities. On the other hand, the authors show that such companies have a good chance for duplicate $\mathrm{R} \& \mathrm{D}$ due to a similar knowledge base which results in lesser opportunities for the acquiring company to develop entirely new technologies. Colombo and Rabbiosi [38] analyzed horizontal mergers and acquisitions and found out that technological similarity of two companies results in negative innovation indicators of the merged company.

The issue of efficiency of high-technology transactions over the long term is still insufficiently studied. S. Dutta and V. Kumar [18] discovered a positive influence of M\&A when analyzing cash flows adjusted in accordance with the industry specifics before and after purchase. The authors found out that purchase of high-tech companies does not result in a significant degradation of the buyer's long-term operational indicators. However, R.P. Rau and T.Vermaelen [62] came to the conclusion that in the long term the evaluation of the purchased company is adjusted because if in the short term the transaction has been overestimated, in the long term the shares' value will come down.

\section{Conclusion}

Thus, the results of the research papers dedicated to M\&A deals in order to purchase technologies and knowledge are mixed in a series of research lines related to the motives which predetermine the actions of managers and the company characteristics. The considered aspects of M\&A deals in order to purchase technologies and knowledge comprise the main fields of scientific research in this sphere.

\section{References}

1. Asimakopoulos G., Whalley J. Market leadership, technological progress and relative performance in the mobile telecommunications industry. Technological Forecasting and Social Change. 2017;123:57-67. DOI: 10.1016/j.techfore.2017.06.021

2. Kapoor R., Lim K. The impact of acquisitions on the productivity of inventors at semiconductor firms: A synthesis of knowledge-based and incentivebased perspectives. The Academy of Management Journal. 2007;50(5):1133-1155. DOI: 10.5465/ amj.2007.27169706

3. Sears J., Hoetker G. Technological overlap, technological capabilities, and resource recombination in technological acquisitions. Strategic Management Journal. 2014;35(1):48-67. DOI: 10.1002/smj.2083

4. Hitt M.A., Hoskisson R.E., Ireland R.D., Harrison, J.S. Effects of acquisitions on R\&D inputs and outputs. Academy of Management Journal. 1991;34(3):693706. DOI: $10.5465 / 256412$

5. Tsai K.H., Wang J.C. External technology acquisition and firm performance: A longitudinal study. Journal of Business Venturing.2008;23(1):91-112. DOI: 10.1016/j.jbusvent.2005.07.002

6. Un C.A., Rodríguez A. Learning from R\&D outsourcing vs. learning by R\&D outsourcing. Technovation. 2018;72-73(Apr.-May):24-33. DOI: 10.1016/j.technovation.2017.12.003 
7. Berchicci L. Towards an open R\&D system: Internal R\&D investment, external knowledge acquisition and innovative performance. Research Policy.2013;42(1):117-127. DOI: 10.1016/j. respol.2012.04.017

8. Kavusan K., Noorderhaven N.G., Duysters G.M. Knowledge acquisition and complementary specialization in alliances: The impact of technological overlap and alliance experience. Research Policy. 2016;45(10):2153-2165. DOI: 10.1016/j.respol.2016.09.013

9. Puranam P., Singh H., Zollo M. Organizing for innovation: managing the coordination-autonomy dilemma in technology acquisitions. Academy of Management Journal. 2006;49(2):263-281. DOI: 10.5465/amj.2006.20786062

10. Cloodt M., Hagedoorn J., Kranenburg V.H. Mergers and acquisitions: Their effect on the innovative performance of companies in high-tech industries. Research Policy. 2006;35(5):642-654. DOI: 10.1016/j. respol.2006.02.007

11. Goergen M., Renneboog L. Shareholder wealth effects of European domestic and cross-border takeover bids. European Financial Management. 2004;10(1):945. DOI: 10.1111/j.1468-036X.2004.00239.x

12. Malumud S., Zucchi F. Liquidity, innovation, and endogenous growth. Journal of Financial Economics. 2019;132(2):519-541. DOI: 10.1016/j. jfineco.2018.11.002

13. Jovanovic B., Rousseau P. The Q-theory of mergers. American Economic Review. 2002;92(2):198-204. DOI: $10.1257 / 000282802320189249$

14. Jovanovic B., Rousseau P. Mergers as reallocation. Review of Economics and Statistics. 2008;90(4):765776. DOI: $10.1162 /$ rest.90.4.765

15. Frey R., Hussinger K. The role of technologies in M\&As: A firm-level comparison of cross-border and domestic deals. ZEW Discussion Paper. 2006;(06069).

16. Amihud Y., Dodd P., Weinstein M. Conglomerate mergers, managerial motives and stockholder wealth. Journal of Banking \& Finance. 1986;10(3):401-410. DOI: $10.1016 /$ S0378-4266(86)80029-2

17. Beitel P., Schiereck D., Wahrenburg M. Explaining M\&A success in European banks. European Financial Management. 2004;10(1):109-139. DOI: 10.1111/j.1468-036X.2004.00242.x

18. Dutta S., Kumar V. Mergers and acquisitions (M\&AS) by R\&D intensive firms. Journal of Risk and Financial Management. 2009;2(1):1-37. DOI:10.3390/ jrfm2010001
19. Agrawal A., Jaffe J.F., Mandelker G.N. The postmerger performance of acquiring firms: A reexamination of an anomaly. The Journal of Finance. 1992;47(4):1605-1621. DOI: 10.1111/j.15406261.1992.tb04674.x

20. Asquith P., Bruner R.F., Mullins D.W. The gains to bidding firms from merger. Journal of Financial Economics. 1983;11(1-4):121-139. DOI: 10.1016/0304-405X(83)90007-7

21. Berkovitch E., Narayanan M.P. Motives for takeovers: An empirical investigation. The Journal of Financial and Quantitative Analysis. 1993;28(3):347-362. DOI: $10.2307 / 2331418$

22. Gaughan P.A. M\&A resurgence: Good or bad? Journal of Corporate Accounting \& Finance. 2011;22(2):3-8. DOI: 10.1002/jcaf.20653

23. Ivashkovskaya I.V., Shamrayeva S.A., Grigoriadi E.E. An empirical analysis of efficiency of corporate diversification in emerging markets: Evidence from BRIC countries. Ekonomicheskii zhurnal Vysshei shkoly ekonomiki $=$ The HSE Economic Journal. 2009;13(3):360-382. (In Russ.).

24. Loughran T., Vijh A.M. Do long-term shareholders benefit from corporate acquisitions? The Journal of Finance. 1997;52(5):1765-1790. DOI: 10.1111/j.15406261.1997.tb02741.x

25. Rosen R.J. Merger momentum and investor sentiment: The stock market reaction to merger announcements. The Journal of Business. 2006;79(2):987-1017. DOI: 10.1086/499146

26. Zollo M., Singh H. Deliberate learning in corporate acquisitions: post-acquisition strategies and integration capability in U.S. bank mergers. Strategic Management Journal. 2004;25(13):1233-1256. DOI: 10.1002/smj.426

27. Ma C., Liu Z. Effects of M\&As on innovation performance: Empirical evidence from Chinese listed manufacturing enterprises. Technology Analysis \& Strategic Management. 2017;29(8):960-972. DOI: $10.1080 / 09537325.2016 .1260104$

28. Konchitchki Y., O'Leary D.E. Event study methodologies in information systems research. International Journal of Accounting Information Systems. 2011;12(2):99-115. DOI: 10.1016/j. accinf.2011.01.002

29. Benou G., Madura J. High-tech acquisitions, firm specific characteristics and the role of investment bank advisors. The Journal of High Technology Management Research. 2005;16(1):101-120. DOI: 10.1016/j.hitech.2005.06.006

30. Kohers N., Kohers T. The value creation potential of high-tech mergers. Financial Analysts Journal. 2000;56(3):40-50. DOI: 10.2469/faj.v56.n3.2359 
31. Lusyana D., Sherif M. Do mergers create value for high-tech firms? The hounds of dotcom bubble. The Journal of High Technology Management Research. 2016;27(2):196-213. DOI: 10.1016/j. hitech.2016.10.009

32. Deshmukh A. Is tech M\&A value-additive? Undergraduate Economic Review. 2012; 9(1). URL: https://digitalcommons.iwu.edu/cgi/viewcontent. cgi? article $=1193 \&$ context $=$ uer

33. Ranft A.L., Lord M.D. Acquiring new technologies and capabilities: A grounded model of acquisition implementation. Organization Science. 2002;13(4):420-441. DOI: 10.1287/orsc.13.4.420.2952

34. Cohen W.M., Levinthal D.A. Absorptive capacity: A new perspective on learning and innovation. Administrative Science Quarterly. 1990;35(1):128152. DOI: $10.2307 / 2393553$

35. Kaplan S.N., ed. Mergers and productivity. Chicago: University of Chicago Press; 2000. 347 p.

36. Maksimovic V., Phillips G., Prabhala N.R. Postmerger restructuring and the boundaries of the firm. Journal of Financial Economics. 2011;102(2):317-343. DOI: 10.1016/j.jfineco.2011.05.013

37. O'Shaughnessy K.C., Flanagan D.J. Determinants of layoff announcements following M\&As: An empirical investigation. Strategic Management Journal. 1998;19(10):989-999. DOI: 10.1002/(SICI)10970266(199810)19:10<989::AID-SMJ994>3.0.CO;2-3

38. Colombo M., Rabbiosi L. Technological similarity, post-acquisition $\mathrm{R} \& \mathrm{D}$ reorganization, and innovation performance in horizontal acquisitions. Research Policy. 2014;43(6):1039-1054. DOI: 10.1016/j. respol.2014.01.013

39. Makri M., Hitt M., Lane P. Complementary technologies, knowledge relatedness, and invention outcomes in high technology mergers and acquisitions. Strategic Management Journal. 2010;31(6):602-628. DOI: 10.1002/smj.829

40. McCarthy K.J., Aalbers H.L. Technological acquisitions: The impact of geography on postacquisition innovative performance. Research Policy. 2016;45(9):1818-1832. DOI: 10.1016/j. respol.2016.05.012

41. King D.R., Slotegraaf R., Kesner I. Performance implications of firm resource interactions in the acquisition of R\&D-intensive firms. Organization Science. 2008;19(2):327-340. DOI: 10.1287/ orsc. 1070.0313

42. Ahuja G., Katila R. Technological acquisition and the innovation performance of acquiring firms: A longitudinal study. Strategic Management Journal. 2001;22(3):197-220. DOI: 10.1002/smj.157
43. Skvortsova I.V., Krasovitskii A.D. Mergers and acquisitions of innovative companies in developed and emerging capital markets: What sets them apart? Korporativnye finansy $=$ Journal of Corporate Finance Research. 2018;12(4):86-98. (In Russ.). DOI: 10.17323/j.jcfr.2073-0438.12.4.2018.86-98

44. Baesu V., Albulescu C.T., Farkas Z.-B., Drăghici A. Determinants of the high-tech sector innovation performance in the European Union: A review. Procedia Technology. 2015;19:371-378. DOI: 10.1016/j.protcy.2015.02.053

45. Phillips G., Zhdanov A. R\&D and the incentives from merger and acquisition activity. The Review of Financial Studies. 2013;26(1):34-78. DOI: 10.1093/ rfs/hhs109

46. Szücs F. M\&A and R\&D: Asymmetric effects on acquirers and targets? Research Policy. 2014;43(7):1264-1273. DOI: 10.1016/j. respol.2014.03.007

47. Gambardella A., Harhoff D., Verspagen B. The value of European patents. European Management Review. 2008;5(2):69-84. DOI: 10.1057/emr.2008.10

48. Scherer F.M., Harhoff D. Technology policy for a world of skew-distributed outcomes. Research Policy. 2000;29(4-5):559-566. DOI: 10.1016/S00487333(99)00089-X

49. Desyllas P., Hughes A. Do high technology acquirers become more innovative? Research Policy, 2010;39(8):1105-1121. DOI: 10.1016/j. respol.2010.05.005

50. Porrini P. Can a previous alliance between an acquirer and a target affect acquisition performance? Journal of Management. 2004;30(4):545-562. DOI: 10.1016/j.jm.2004.02.003

51. Campa J.M., Hernando I. Shareholder value creation in European M\&As. European Financial Management. 2004;10(1):47-81. DOI: 10.1111/j.1468036X.2004.00240.x

52. Moeller S.B., Schlingemann F.P. Global diversification and bidder gains: A comparison between crossborder and domestic acquisitions. Journal of Banking \& Finance. 2005;29(3):533-564. DOI: 10.1016/j. jbankfin.2004.05.018

53. Boateng A., Qian W., Tianle Y. Cross-border M\&As by Chinese firms: An analysis of strategic motives and performance. Thunderbird International Business Review. 2008;50(4):259-270. DOI: 10.1002/tie.20203

54. Seth A., Song K.P., Perrit R.R. Value creation and destruction in cross-border acquisitions: an empirical analysis of foreign acquisition of U.S. firms. Strategic Management Journal. 2002;23(10):921-940. DOI: 10.1002/smj.264 
55. Kohli R., Mann B.J.S. Analyzing determinants of value creation in domestic and cross border acquisitions in India. International Business Review. 2012;21(6):998-1016. DOI: 10.1016/j. ibusrev.2011.11.006

56. Yoon H.D., Lee J.J. Technology-acquiring crossborder M\&As by emerging market firms: Role of bilateral trade openness. Technology Analysis and Strategic Management. 2016;28(3):251-265. DOI: $10.1080 / 09537325.2015 .1093618$

57. Hagedoorn J., Duysters G. The effect of mergers and acquisitions on the technological performance of companies in high-tech environment. Technology Analysis and Strategic Management. 2002;14(1):6785. DOI: $10.1080 / 09537320220125892$

58. Francoeur C. The long-run performance of crossborder mergers and acquisitions: Evidence to support the internalization. Corporate Ownership and Control. 2007;4(2-2):312-323. DOI: 10.22495/ cocv $4 \mathrm{i} 4 \mathrm{p} 8$
59. Grigor'eva S.A., Tarasova E.O. Are international M\&A deals effective for buying companies from BRICS countries? In: Ivashkovskaya I.V., ed. Strategic financial decisions of companies in emerging capital markets. Moscow: KnoRus; 2019:201-229. (In Russ.).

60. Radygin A.D., Entov R.M. M\&A market: New theoretical approaches. Ekonomicheskaya politika = Economic Policy. 2010;(5):67-91. (In Russ.).

61. Hagedoorn J. Understanding the rationale of strategic technology partnering: Interorganizational modes of cooperation and sectoral differences. Strategic Management Journal. 1993;14(5):371-385. DOI: 10.1002/smj.4250140505

62. Rau P.R., Vermaelen T. Glamour, value and the postacquisition performance of acquiring firms. Journal of Financial Economics. 1998;49(2):223-253. DOI: $10.1016 /$ S0304-405X(98)00023-3 